Organic \&

Biomolecular

Chemistry
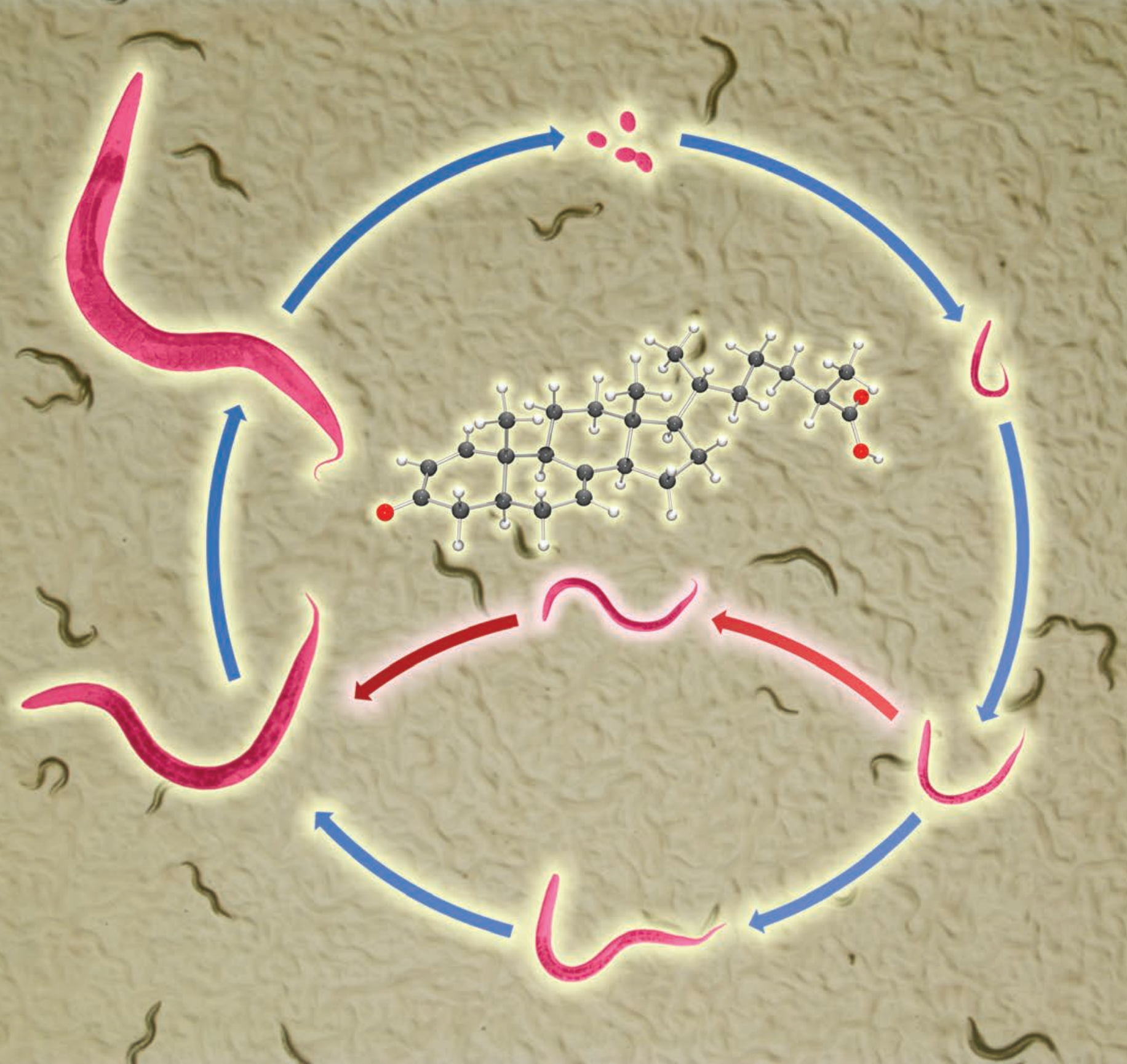

\title{
COMMUNICATION
}

RSCPublishing

Hans-Joachim Knölker et al.

Stereoselective synthesis and hormonal activity of novel dafachronic acids and naturally occurring steroids isolated from corals

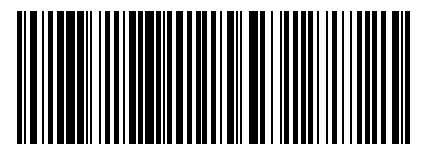

$1477-0520(2012) 10: 21 ; 1-G$ 


\title{
Organic \& \\ Biomolecular \\ Chemistry
}

Cite this: Org. Biomol. Chem., 2012, 10,4159

wWW.rsc.org/obc

COMMUNICATION

\section{Stereoselective synthesis and hormonal activity of novel dafachronic acids and naturally occurring steroids isolated from corals $\uparrow$}

\author{
Ratni Saini, ${ }^{a}$ Sebastian Boland, ${ }^{b}$ Olga Kataeva, ${ }^{a}$ Arndt W. Schmidt, ${ }^{a}$ Teymuras V. Kurzchalia ${ }^{b}$ and \\ Hans-Joachim Knölker*a
}

Received 23rd February 2012, Accepted 8th March 2012

DOI: $10.1039 / \mathrm{c} 20 b 25394$ a

A stereoselective synthesis of $(25 S)-\Delta^{1}-,(25 S)-\Delta^{1,4}-,(25 S)-$ $\Delta^{1,7}$-, $(25 S)-\Delta^{8(14)}$-, (25S)- $\Delta^{4,6,8(14)}$-dafachronic acid, methyl $(25 S)-\Delta^{1,4}$-dafachronate and (25S)-5 $\alpha$-hydroxy-3,6-dioxocholest-7-en-26-oic acid is described. (25S)- $\Delta^{1,4}$-Dafachronic acid and its methyl ester are natural products isolated from corals and have been obtained by synthesis for the first time. (25S)5o-Hydroxy-3,6-dioxocholest-7-en-26-oic acid represents a promising synthetic precursor for cytotoxic marine steroids.

The genes $d a f-9$ and $d a f-12$ play a key role in controlling the life cycle and longevity of the nematode Caenorhabditis elegans. ${ }^{1,2}$ It was found that daf- 9 encodes a cytochrome P450 oxidase which completes the synthesis of dafachronic acids $\mathbf{1}$ and $\mathbf{2}$ (Fig. 1). These steroidal acids are ligands for the hormone receptor DAF-12. ${ }^{3}$ By binding of dafachronic acids, DAF-12 is inactivated and the nematodes undergo normal reproductive development. In the absence of these ligands, DAF-12 is activated and dauer larvae are generated. ${ }^{2}$

Due to their hormonal activity and the importance for investigations in developmental biology, several synthetic routes have been reported for the dafachronic acids. ${ }^{4-10}$ We have developed a highly efficient synthetic route to $(25 S)-\Delta^{4}$-dafachronic acid (1) and (25S)- $\Delta^{7}$-dafachronic acid (2). ${ }^{6,10} \mathrm{~A}$ crucial intermediate for our approach is the orthogonally diprotected diol $\mathbf{4}$ which has

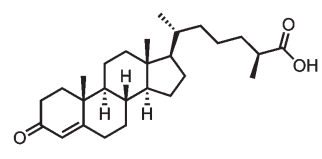

$1(25 S)-\Delta^{4}-$ Dafachronic acid

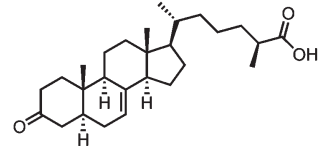

$2(25 S)-\Delta^{7}$-Dafachronic acid
Fig. 1 Steroidal ligands for the hormonal DAF-12 receptor of $C$. elegans.

\footnotetext{
${ }^{a}$ Department Chemie, Technische Universität Dresden, Bergstrasse 66, 01069 Dresden, Germany.E-mail: hans-joachim.knoelker@tu-dresden. de; Fax: +49 351-463-37030

${ }^{b}$ Max Planck Institute of Molecular Cell Biology and Genetics,

Pfotenhauerstrasse 108, 01307 Dresden, Germany

$\dagger$ Electronic supplementary information (ESI) available: ${ }^{1} \mathrm{H}$ and ${ }^{13} \mathrm{C}$ NMR spectra of compounds 9-11, 13, 16, 20 and 23. 2D NMR spectra (COSY, HSQC, HMBC and NOESY) of compound 20. CCDC 867379 and 867380 . For ESI and crystallographic data in CIF or other electronic format see DOI: 10.1039/c2ob25394a
}

been prepared from $3 \beta$-hydroxychol-5-en-24-oic acid (3) in 8 steps and $66 \%$ overall yield using an Evans aldol reaction as key step (Scheme 1). ${ }^{6}$ With 4 as relay compound both hormonally active dafachronic acids became readily accessible. Desilylation of 4, Oppenauer oxidation with isomerization of the double
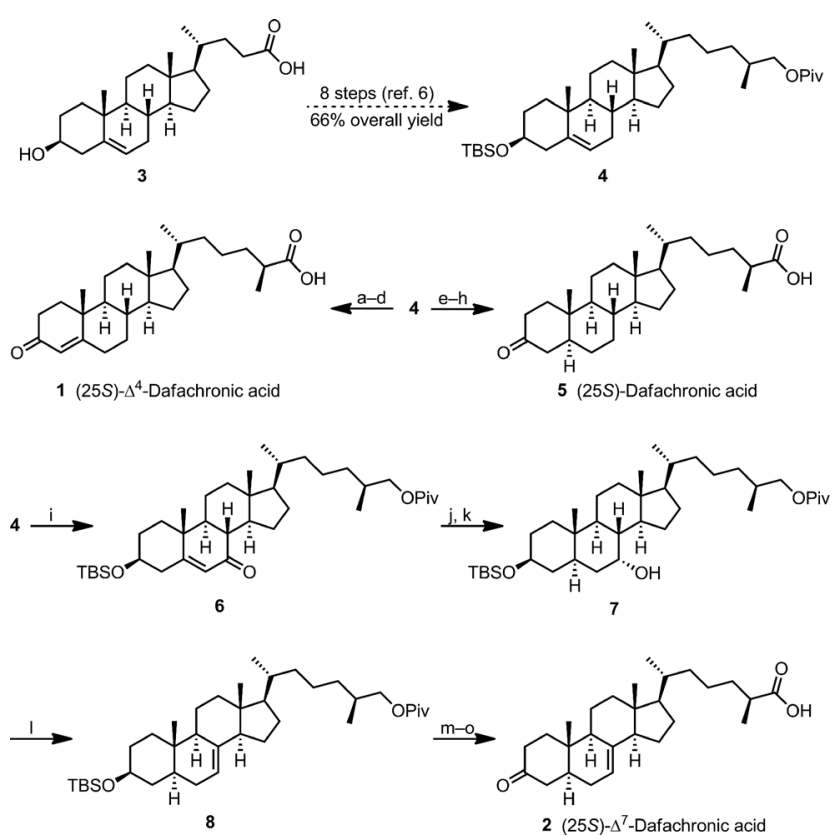

Scheme 1 Synthesis of $(25 S)-\Delta^{4}$ - and $(25 S)-\Delta^{7}$-dafachronic acid (1) and (2) and (25S)-dafachronic acid (5) using the orthogonally diprotected diol $\mathbf{4}$ as relay compound. Reagents and conditions: (a) 1.5 equiv. TBAF, THF, reflux, $17 \mathrm{~h}, 92 \%$; (b) 1.5 equiv. $\mathrm{Al}(\mathrm{OiPr})_{3}$, acetonetoluene (1:9), $100{ }^{\circ} \mathrm{C}, 5 \mathrm{~h}, 86 \%$; (c) 2.0 equiv. $\mathrm{NaOMe}, \mathrm{MeOH}, \mathrm{rt}, 5 \mathrm{~d}$, $87 \%$; (d) 5.0 equiv. Jones reagent, $0{ }^{\circ} \mathrm{C}, 2 \mathrm{~h}, 85 \%$; (e) 1.5 equiv. TBAF, THF, reflux, $17 \mathrm{~h}$; (f) 4.0 equiv. $\mathrm{LiAlH}_{4}$, THF, rt, $16 \mathrm{~h}, 93 \%$ for two steps; (g) $10 \% \mathrm{Pd} / \mathrm{C}, \mathrm{H}_{2}, \mathrm{MeOH}-\mathrm{CH}_{2} \mathrm{Cl}_{2}(1: 1)$, rt, $24 \mathrm{~h}, 99 \%$; (h) 5.0 equiv. Jones reagent, acetone, $0{ }^{\circ} \mathrm{C}, 60 \mathrm{~min}, 88 \%$; (i) 4.0 equiv. PDC, 8.0 equiv. $t \mathrm{BuOOH}$, Celite ${ }^{\circledR}$, benzene, $0{ }^{\circ} \mathrm{C}$ to $\mathrm{rt}, 41 \mathrm{~h}, 75 \%$; (j) $10 \%$ $\mathrm{Pd} / \mathrm{C}, \mathrm{H}_{2}$, EtOAc, rt, 16 h, 95\%; (k) 1.3 equiv. L-Selectride ${ }^{\circledR}$, THF, $-78{ }^{\circ} \mathrm{C}, 1.5 \mathrm{~h}, 90 \%$; (1) 5.0 equiv. $\mathrm{SOCl}_{2}$, pyridine, $0{ }^{\circ} \mathrm{C}, 40 \mathrm{~min}, 87 \%$; (m) 1.5 equiv. TBAF, THF, reflux, 16 h; (n) 4.0 equiv. $\mathrm{LiAlH}_{4}, \mathrm{THF}$, $0{ }^{\circ} \mathrm{C}$ to $\mathrm{rt}, 17 \mathrm{~h}, 82 \%$ for two steps; (o) 5.0 equiv. Jones reagent, acetone, $0{ }^{\circ} \mathrm{C}, 90 \mathrm{~min}, 89 \%$. 

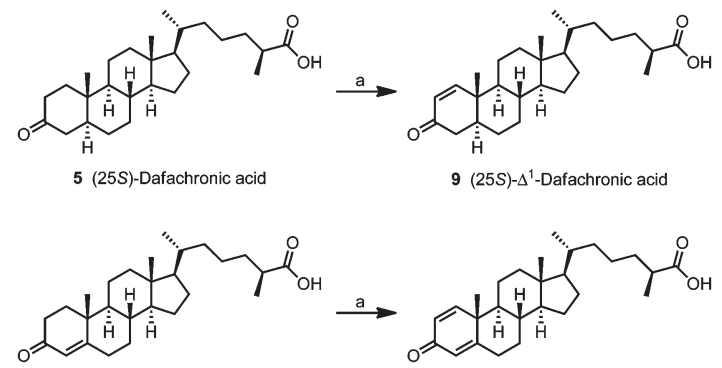

$1(25 S)-\Delta^{4}-$ Dafachronic acid

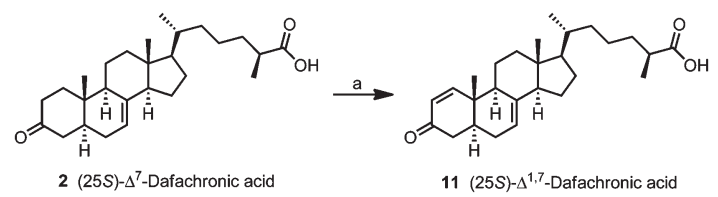

Scheme 2 Synthesis of $(25 S)-\Delta^{1}$-, $(25 S)-\Delta^{1,4}$ - and $(25 S)-\Delta^{1,7}$-dafachronic acid (9), (10) and (11). Reagents and conditions: (a) $10 \mathrm{~mol} \%$ $\mathrm{Pd}\left(\mathrm{OCOCF}_{3}\right)_{2}, 10 \mathrm{~mol} \% \mathrm{DMSO}, \mathrm{O}_{2}, \mathrm{HOAc}, 80^{\circ} \mathrm{C}, 24 \mathrm{~h}, 93 \%$ 9, 75\% $10,86 \% 11$.

bond, cleavage of the pivalate and Jones oxidation led to (25S)$\Delta^{4}$-dafachronic acid (1) in an improved $39 \%$ overall yield (12 steps). Alternatively, sequential removal of both protecting groups of compound $\mathbf{4}$ by desilylation with TBAF and subsequent cleavage of the pivalate via reduction using lithium aluminium hydride, catalytic hydrogenation of the double bond and Jones oxidation provided the unnatural $(25 S)$-dafachronic acid (5) (12 steps, 53\% overall yield). For the synthesis of (25S)- $\Delta^{7}$ dafachronic acid (2), the double bond of the orthogonally diprotected diol $\mathbf{4}$ was moved from the 5,6- to the 7,8-position via the following four-step sequence. Allylic oxidation at $\mathrm{C}-7$ to the enone 6, hydrogenation of the 5,6-double bond, stereoselective reduction to the $7 \alpha$-alcohol 7 and finally, elimination of water afforded compound $\mathbf{8}$. Removal of both protecting groups of $\mathbf{8}$ (first of the silyl and then of the pivaloyl group) followed by Jones oxidation provided $(25 S)$ - $\Delta^{7}$-dafachronic acid (2) in 15 steps and $27 \%$ overall yield.

Herein, we describe an efficient synthesis of novel dafachronic acids and of naturally occurring steroidal acids which have been isolated from corals. A first investigation of their hormonal activity is also presented. Using the palladium(II)-catalyzed process reported by Stahl et al. 3-oxosteroids can be regioselectively dehydrogenated at the 1,2-position. ${ }^{11}$ Thus, $(25 S)$-dafachronic acid (5), (25S)- $\Delta^{4}$-dafachronic acid (1) and $(25 S)-\Delta^{7}-$ dafachronic acid (2) have been transformed directly into (25S)$\Delta^{1}$-dafachronic acid (9), (25S)- $\Delta^{1,4}$-dafachronic acid (10) and $(25 S)-\Delta^{1,7}$-dafachronic acid (11) in yields ranging from 75 to $93 \%$ (Scheme 2) $\$^{11}$ In this context, it is noteworthy that compound $\mathbf{1 0}$ was recently described as a natural product. Namikoshi et al. isolated (25S)-3-oxocholesta-1,4-dien-26-oic acid (10) from the Indonesian soft coral Minabea sp. ${ }^{12}$ Thus, our present route also constitutes the first synthesis of this natural product.

In an alternative approach to $(25 S)-\Delta^{1,4}$-dafachronic acid (10), $(25 S)-\Delta^{4}$-dafachronic acid (1) was initially converted to the corresponding methyl ester 12 (Scheme 3). Dehydrogenation with 1.3 equiv. 2,3-dichloro-5,6-dicyano-1,4-benzoquinone (DDQ) in the presence of tert-butyldimethylsilyl chloride (TBSCl)

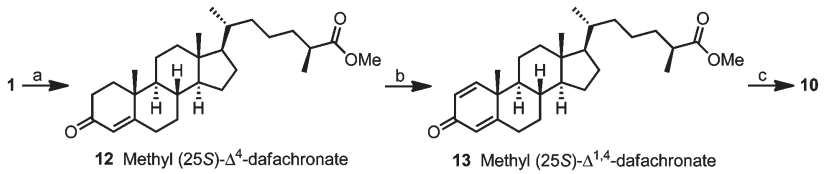

Scheme 3 Synthesis of $\mathbf{1 3}$ and $(25 S)-\Delta^{1,7}$-dafachronic acid (10). Reagents and conditions: (a) cat. $\mathrm{H}_{2} \mathrm{SO}_{4}, \mathrm{MeOH}$, reflux, 7 h, 96\%; (b) 1.3 equiv. DDQ, 5 mol\% TBSCl, dioxane, rt, 24 h, 65\% (20\% 12); (c) 3.0 equiv. $\mathrm{LiOH}, \mathrm{THF}-\mathrm{MeOH}-\mathrm{H}_{2} \mathrm{O}(1: 1: 1)$, rt, 24 h, $88 \%$.
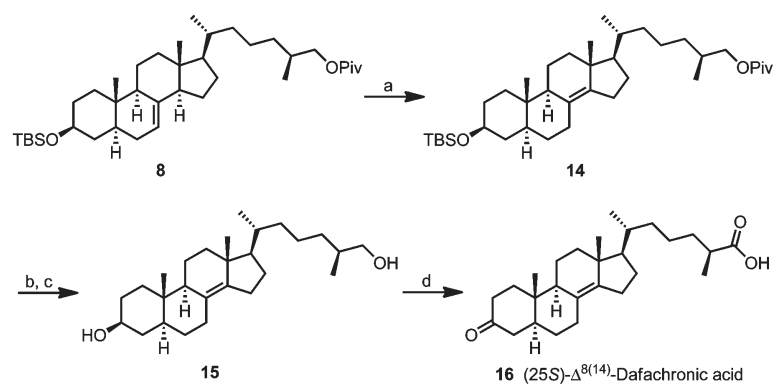

Scheme 4 Synthesis of (25S)- $\Delta^{8(14)}$-dafachronic acid (16). Reagents and conditions: (a) $\mathrm{PtO}_{2}, \mathrm{H}_{2}$, EtOAc-HOAc (10:1), rt, 2 d, 94\%; (b) 1.5 equiv. TBAF, THF, rt, $24 \mathrm{~h}$; (c) 2.0 equiv. $\mathrm{LiAlH}_{4}$, THF, $0{ }^{\circ} \mathrm{C}$ to rt, $8 \mathrm{~h}, 93 \%$ for two steps; (d) 5.0 equiv. Jones reagent, acetone, $0{ }^{\circ} \mathrm{C}, 2 \mathrm{~h}$, $78 \%$.

afforded the cross-conjugated dienone $\mathbf{1 3}$ in $65 \%$ yield along with $20 \%$ of starting material. $\$^{13}$ The course of this reaction is much more difficult to control as compared to the procedure described by Stahl et al. Use of larger amounts of DDQ by overoxidation led to methyl (25S)- $\Delta^{1,4,6}$-dafachronate. Interestingly, methyl $(25 S)$ - $\Delta^{1,4}$-dafachronate (13) also represents a natural product. A few years ago, Zubía et al. isolated methyl 3-oxocholesta-1,4-dien-26-oate from the Antarctic octocoral Anthomastus bathyproctus. ${ }^{14}$ However, they left the configuration at C-25 of their natural product undetermined. A comparison of the value reported by Zubía et al. for the ${ }^{13} \mathrm{C}$ NMR signal of C-27 ( $\delta=$ $17.0 \mathrm{ppm})^{14}$ with the value we have observed for C-27 of compound $13(\delta=17.23 \mathrm{ppm})$ led us to assign an $S$ configuration for C-25 of natural methyl 3-oxocholesta-1,4-dien-26-oate. Our assignment is based on the distinct difference found between the ${ }^{13} \mathrm{C}$ NMR signals for $\mathrm{C}-27$ of the $(25 S)$ and the $(25 R)$ series: This difference is observed for the carboxylic acids (compare Table 2 in ref. 10) as well as for the esters. ${ }^{5 b, 6 b}$

Starting from $\mathbf{8}$, we synthesised $(25 S)-\Delta^{8(14)}$-dafachronic acid (16) (Scheme 4). Isomerisation of the double bond provided quantitatively the diprotected $\Delta^{8(14)}$-compound $\mathbf{1 4} .{ }^{15}$ Cleavage of first the silyl and then the pivaloyl protecting group led to the $\Delta^{8(14)}$-steroiddiol $\mathbf{1 5}$. The regio- and the stereochemistry of $\mathbf{1 5}$ has been confirmed by an X-ray crystal structure determination (Fig. 2).\& Finally, Jones oxidation afforded $(25 S)-\Delta^{8(14)}$-dafachronic acid (16) in 16 steps and $25 \%$ overall yield based on $3 .+$

In a further study, we investigated the chemistry of a corresponding B-ring diene 3 3,26 -steroid diol resembling vitamin D. ${ }^{16}$ Starting from enone $\mathbf{6}$, an additional double bond at position 7,8 was introduced via the Shapiro reaction (Scheme 5). ${ }^{17}$ Conversion of $\mathbf{6}$ to the tosylhydrazone $\mathbf{1 7}$ followed by treatment with an excess of lithium hydride provided the 5,7-diene 18 . 


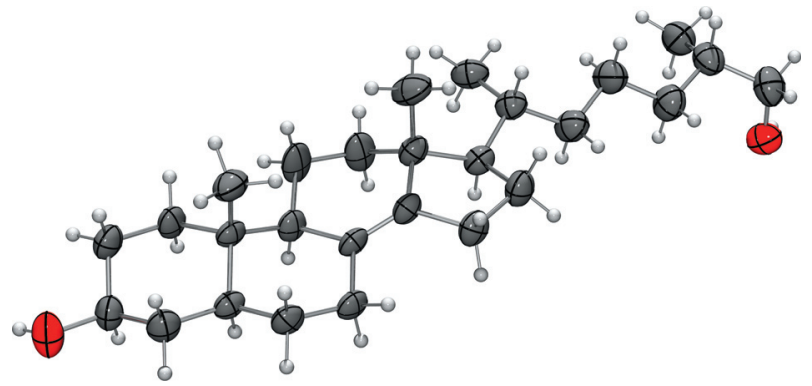

Fig. 2 Molecular structure of (25S)-cholest-8(14)-en-33,26-diol (15) in the crystal (ORTEP plot at the $50 \%$ probability level).
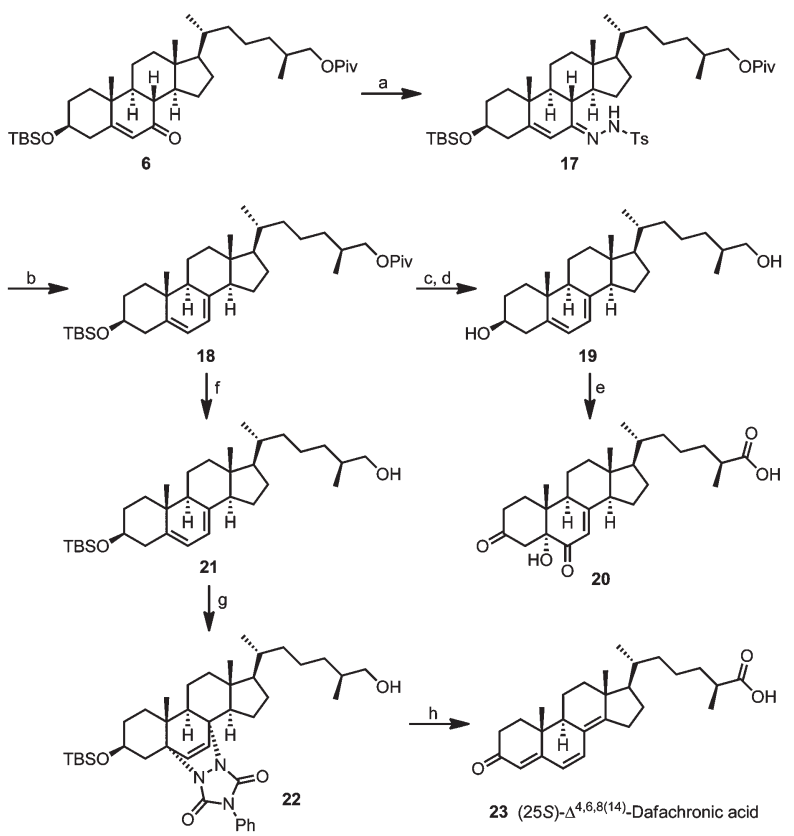

$23(25 S)-\triangle^{4,6,8(14)}$-Dafachronic acid

Scheme 5 Synthesis of (25S)- $\Delta^{4,6,8(14)}$-dafachronic acid (23). Reagents and conditions: (a) 7.5 equiv. $p$-toluenesulfonyl hydrazide, THF, reflux, $24 \mathrm{~h}, 81 \%$; (b) 100 equiv. $\mathrm{LiH}$, toluene, $100{ }^{\circ} \mathrm{C}, 4 \mathrm{~h}, 66 \%$; (c) 3.0 equiv. TBAF, THF, rt, 24 h, 90\%; (d) 1.2 equiv. $\mathrm{LiAlH}_{4}, \mathrm{Et}_{2} \mathrm{O}-\mathrm{CH}_{2} \mathrm{Cl}_{2}$ (1:1), $0{ }^{\circ} \mathrm{C}$ to rt, $4 \mathrm{~h}, 84 \%$; (e) 5.0 equiv. Jones reagent, acetone, $0{ }^{\circ} \mathrm{C}, 30 \mathrm{~min}$, $50 \%$; (f) 1.5 equiv. $\mathrm{LiAlH}_{4}, \mathrm{CH}_{2} \mathrm{Cl}_{2}-\mathrm{Et}_{2} \mathrm{O}(1: 1), 0{ }^{\circ} \mathrm{C}$ to rt, $3 \mathrm{~h}, 100 \%$; (g) 1.3 equiv. 4-phenyl-1,2,4-triazoline-3,5-dione, $\mathrm{CH}_{2} \mathrm{Cl}_{2}$, rt, $30 \mathrm{~min}$, $86 \%$; (h) 5.0 equiv. Jones reagent, acetone, $0{ }^{\circ} \mathrm{C}, 30 \mathrm{~min}, 75 \%$.

Removal of the silyl and then the pivaloyl protecting group afforded (25S)-cholesta-5,7-diene-33,26-diol (19). At this stage, the structural assignment has been additionally confirmed by X-ray analysis of single crystals of $\mathbf{1 9}$ (Fig. 3). I Jones oxidation of compound 19 generated as expected the ketone at C-3 and the carboxylic acid at $\mathrm{C}-26$. However, an additional dioxygenation of the 5,6-double bond led to (25S)-5 $\alpha$-hydroxy-3,6-dioxocholest-7-en-26-oic acid (20). $\$$ This structural assignment has been confirmed by extensive 2D NMR experiments (Fig. 4 and ESI $\dagger$ ). It is noteworthy that Shin et al. have isolated bioactive steroids from the gorgonian Acalycigorgia inermis with structural features very similar to compound $20 .{ }^{18}$ The synthesis of these natural products is currently in progress in our laboratories. Cleavage of the pivalate of the 5,7-diene 18 led to compound 21 which on Diels-Alder cycloaddition with 4-phenyl-1,2,4-

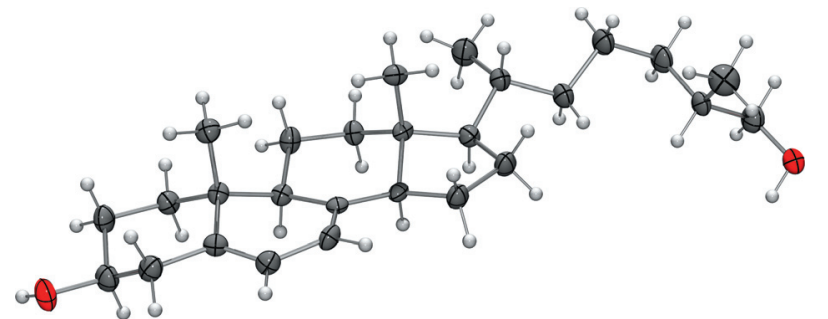

Fig. 3 Molecular structure of (25S)-cholesta-5,7-diene-3ß,26-diol (19) in the crystal (ORTEP plot at the $50 \%$ probability level).

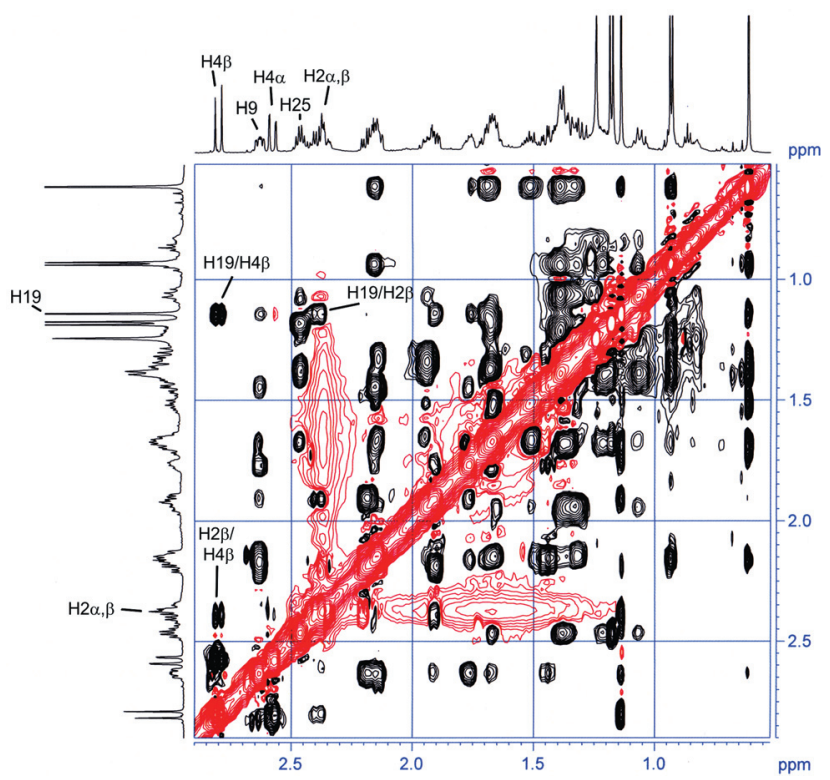

Fig. 4 NOESY spectrum of compound $20\left(600 \mathrm{MHz}, \mathrm{CDCl}_{3}\right)$.

triazoline-3,5-dione (PTAD) afforded the adduct 22. ${ }^{19}$ Jones oxidation of $\mathbf{2 2}$ proceeded with concomitant elimination of the heterocycle and provided directly $(25 S)-\Delta^{4,6,8(14)}$-dafachronic acid (23) $)$.

Finally, we have tested the hormonal activity of the novel $(25 S)$-dafachronic acids in rescuing worms from dauer arrest. The details of our bioassay protocol have been described previously. ${ }^{5 b, 6 b}$ Mutant worms $d a f-9(d h-6)$ are lacking the DAF-9 activity. Therefore, they cannot produce the ligands for the DAF-12 receptor and arrest as dauer larvae. Feeding of $d a f-9(d h-$ 6) mutant worms with the (25S)-dafachronic acids described above led to a rescue from dauer arrest and to the development of adults. The ability to rescue the $d a f-9(d h-6)$ mutant worms from dauer arrest and to induce normal development of adults varies significantly for the different (25S)-dafachronic acids (Fig. 5).

The activity of the (25S)-dafachronic acids is dependent on the location of the double bond(s). The most active compounds are (25S)- $\Delta^{1,7}$-dafachronic acid (11) and $(25 S)-\Delta^{7}$-dafachronic acid (2) with a double bond at the 7,8-position as a common structural feature. They induce normal development of the worms already at concentrations below $10 \mathrm{nM}$. (25S)-- $\Delta^{1}$-Dafachronic acid (9), (25S)- $\Delta^{4}$-dafachronic acid (1) and $(25 S)-\Delta^{1,4}$ dafachronic acid (10) belong to the group of second most active 


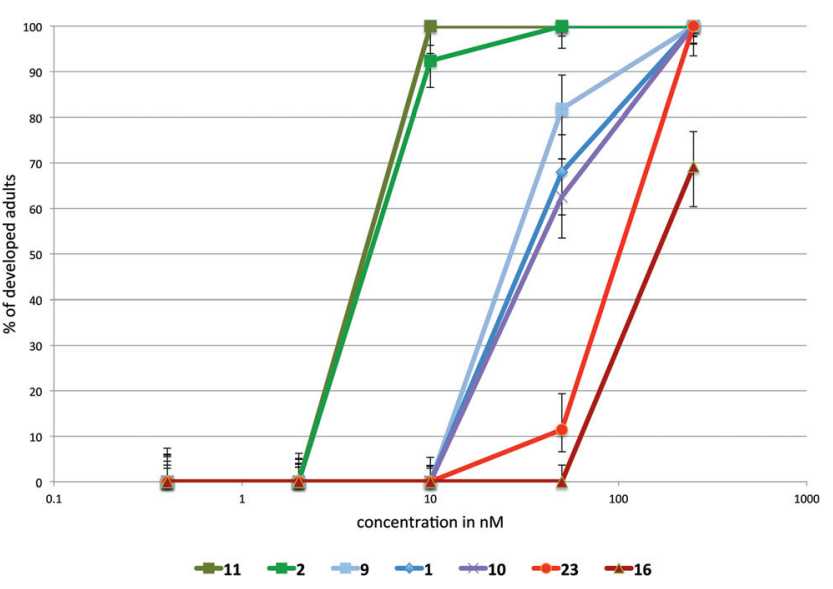

Fig. 5 Hormonal activity of the different dafachronic acids.

compounds which at concentrations of $50 \mathrm{nM}$ effect a rescue from dauer arrest for about $60-80 \%$ of the worms. (25S)$\Delta^{4,6,8(14)}$-Dafachronic acid (23) and (25S)- $\Delta^{8(14)}$-dafachronic acid (16) are the least active compounds in this series. Previously, we have shown that (25S)-dafachronic acid (5) has about the same activity as (25S)- $\Delta^{4}$-dafachronic acid (1). ${ }^{6 b, 10}$ The present results emphasise the importance of the double bond at position 7,8 for the hormonal activity of dafachronic acids.

We are grateful to the ESF EuroMembrane Network (DFG grant KN 240/13-1) and the Deutsche Forschungsgemeinschaft (grant KN 240/16-1) for financial support of our project.

\section{Notes and references}

† Spectroscopic data for (25S)- $\Delta^{1}$-dafachronic acid (9): Colourless crystals, mp $112-115{ }^{\circ} \mathrm{C} ;{ }^{13} \mathrm{C}$ NMR and DEPT $\left(125 \mathrm{MHz}, \mathrm{CDCl}_{3}\right): \delta=$ $12.17\left(\mathrm{CH}_{3}\right), 12.95\left(\mathrm{CH}_{3}\right), 17.00\left(\mathrm{CH}_{3}\right), 18.56\left(\mathrm{CH}_{3}\right), 21.22\left(\mathrm{CH}_{2}\right)$, $23.70\left(\mathrm{CH}_{2}\right), 24.08\left(\mathrm{CH}_{2}\right), 27.63\left(\mathrm{CH}_{2}\right), 28.20\left(\mathrm{CH}_{2}\right), 31.28\left(\mathrm{CH}_{2}\right)$, $34.01\left(\mathrm{CH}_{2}\right), 35.62(\mathrm{CH}), 35.64(\mathrm{CH}), 35.69\left(\mathrm{CH}_{2}\right), 38.96(\mathrm{C}), 39.26$ $(\mathrm{CH}), 39.76\left(\mathrm{CH}_{2}\right), 40.98\left(\mathrm{CH}_{2}\right), 42.70(\mathrm{C}), 44.28(\mathrm{CH}), 49.91(\mathrm{CH})$, $56.10(\mathrm{CH}), 56.33(\mathrm{CH}), 127.32(\mathrm{CH}), 158.68(\mathrm{CH}), 181.95(\mathrm{C}=\mathrm{O})$,

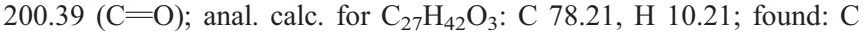
77.61, H 10.35 .

Spectroscopic data for $(25 S)-\Delta^{1,4}$-dafachronic acid (10): Light yellow crystals, mp $129-130{ }^{\circ} \mathrm{C} ;{ }^{13} \mathrm{C}$ NMR and DEPT $\left(125 \mathrm{MHz}, \mathrm{CDCl}_{3}\right): \delta=$ $12.03\left(\mathrm{CH}_{3}\right), 17.02\left(\mathrm{CH}_{3}\right), 18.49\left(\mathrm{CH}_{3}\right), 18.65\left(\mathrm{CH}_{3}\right), 22.84\left(\mathrm{CH}_{2}\right)$, $23.69\left(\mathrm{CH}_{2}\right), 24.35\left(\mathrm{CH}_{2}\right), 28.09\left(\mathrm{CH}_{2}\right), 32.92\left(\mathrm{CH}_{2}\right), 33.67\left(\mathrm{CH}_{2}\right)$, $33.99\left(\mathrm{CH}_{2}\right), 35.49(\mathrm{CH}), 35.56(\mathrm{CH}), 35.64\left(\mathrm{CH}_{2}\right), 39.28(\mathrm{CH}), 39.45$ $\left(\mathrm{CH}_{2}\right), 42.64(\mathrm{C}), 43.66(\mathrm{C}), 52.34(\mathrm{CH}), 55.41(\mathrm{CH}), 55.94(\mathrm{CH})$, $123.71(\mathrm{CH}), 127.37(\mathrm{CH}), 156.20(\mathrm{CH}), 169.69(\mathrm{C}), 181.97(\mathrm{C}=\mathrm{O})$, $186.56(\mathrm{C}=\mathrm{O})$; anal. calc. for $\mathrm{C}_{27} \mathrm{H}_{40} \mathrm{O}_{3}$ : C 78.60, $\mathrm{H}$ 9.77; found: $\mathrm{C}$ 78.70, H 9.85 .

Spectroscopic data for $(25 S)-\Delta^{1,7}$-dafachronic acid (11): Colourless crystals, mp $100-102{ }^{\circ} \mathrm{C} ;{ }^{13} \mathrm{C}$ NMR and DEPT $\left(125 \mathrm{MHz}, \mathrm{CDCl}_{3}\right): \delta=$ $11.92\left(\mathrm{CH}_{3}\right), 12.60\left(\mathrm{CH}_{3}\right), 17.03\left(\mathrm{CH}_{3}\right), 18.74\left(\mathrm{CH}_{3}\right), 21.55\left(\mathrm{CH}_{2}\right)$, $22.86\left(\mathrm{CH}_{2}\right), 23.76\left(\mathrm{CH}_{2}\right), 27.87\left(\mathrm{CH}_{2}\right), 28.56\left(\mathrm{CH}_{2}\right), 34.01\left(\mathrm{CH}_{2}\right)$, $35.64\left(\mathrm{CH}_{2}\right), 36.03(\mathrm{CH}), 37.37(\mathrm{C}), 39.27\left(\mathrm{CH}_{2}\right.$ and $\left.\mathrm{CH}\right), 39.64(\mathrm{CH})$, $40.11\left(\mathrm{CH}_{2}\right), 43.54(\mathrm{C}), 45.24(\mathrm{CH}), 55.15(\mathrm{CH}), 55.97(\mathrm{CH}), 117.83$ $(\mathrm{CH}), 127.13(\mathrm{CH}), 138.67(\mathrm{C}), 157.43(\mathrm{CH}), 181.71(\mathrm{C}=\mathrm{O}), 199.90$ $(\mathrm{C}=\mathrm{O})$.

Spectroscopic data for methyl $(25 S)-\Delta^{1,4}$-dafachronate (13): Light yellow crystals, mp $75-80{ }^{\circ} \mathrm{C} ;{ }^{13} \mathrm{C} \mathrm{NMR}$ and DEPT $\left(75 \mathrm{MHz}, \mathrm{CDCl}_{3}\right)$ : $\delta=12.03\left(\mathrm{CH}_{3}\right), 17.23\left(\mathrm{CH}_{3}\right), 18.48\left(\mathrm{CH}_{3}\right), 18.67\left(\mathrm{CH}_{3}\right), 22.84\left(\mathrm{CH}_{2}\right)$, $23.79\left(\mathrm{CH}_{2}\right), 24.35\left(\mathrm{CH}_{2}\right), 28.08\left(\mathrm{CH}_{2}\right), 32.91\left(\mathrm{CH}_{2}\right), 33.67\left(\mathrm{CH}_{2}\right)$, $34.27\left(\mathrm{CH}_{2}\right), 35.51(\mathrm{CH}), 35.55(\mathrm{CH}), 35.65\left(\mathrm{CH}_{2}\right), 39.47\left(\mathrm{CH}_{2}\right), 39.50$ $(\mathrm{CH}), 42.65(\mathrm{C}), 43.62(\mathrm{C}), 51.43\left(\mathrm{CH}_{3}\right), 52.36(\mathrm{CH}), 55.43(\mathrm{CH})$, $55.98(\mathrm{CH}), 123.75(\mathrm{CH}), 127.42(\mathrm{CH}), 156.00(\mathrm{CH}), 169.44(\mathrm{C})$, $177.37(\mathrm{C}=\mathrm{O}), 186.44(\mathrm{C}=\mathrm{O})$; anal. calc. for $\mathrm{C}_{28} \mathrm{H}_{42} \mathrm{O}_{3}: \mathrm{C} 78.83, \mathrm{H}$ 9.92; found: C 78.94, H 9.77 .
Spectroscopic data for $(25 S)-\Delta^{8(14)}$-dafachronic acid (16): Colourless crystals, mp $138-140{ }^{\circ} \mathrm{C} ;{ }^{13} \mathrm{C}$ NMR and DEPT $\left(125 \mathrm{MHz}, \mathrm{CDCl}_{3}\right): \delta=$ $11.93\left(\mathrm{CH}_{3}\right), 16.99\left(\mathrm{CH}_{3}\right), 18.25\left(\mathrm{CH}_{3}\right), 18.97\left(\mathrm{CH}_{3}\right), 20.05\left(\mathrm{CH}_{2}\right)$, $23.59\left(\mathrm{CH}_{2}\right), 25.89\left(\mathrm{CH}_{2}\right), 27.01\left(\mathrm{CH}_{2}\right), 29.14\left(\mathrm{CH}_{2}\right), 29.29\left(\mathrm{CH}_{2}\right)$, $34.04\left(\mathrm{CH}_{2}\right), 34.27(\mathrm{CH}), 35.54\left(\mathrm{CH}_{2}\right), 36.94\left(\mathrm{CH}_{2}\right), 37.11(\mathrm{C}), 38.04$ $\left(\mathrm{CH}_{2}\right), 38.24\left(\mathrm{CH}_{2}\right), 39.34(\mathrm{CH}), 42.74(\mathrm{C}), 44.66\left(\mathrm{CH}_{2}\right), 46.39(\mathrm{CH})$, $48.74(\mathrm{CH}), 56.79(\mathrm{CH}), 125.41(\mathrm{C}), 143.45(\mathrm{C}), 182.50(\mathrm{C}=\mathrm{O})$,

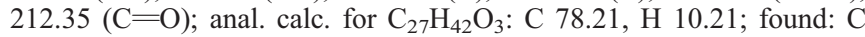
78.30, H 10.28.

Spectroscopic data for $(25 S)$-5 $\alpha$-hydroxy-3,6-dioxocholest-7-en-26oic acid (20): Light yellow crystals; ${ }^{13} \mathrm{C}$ NMR and DEPT $(150 \mathrm{MHz}$, $\left.\mathrm{CDCl}_{3}\right): \delta=12.48\left(\mathrm{CH}_{3}\right), 15.86\left(\mathrm{CH}_{3}\right), 17.04\left(\mathrm{CH}_{3}\right), 18.72\left(\mathrm{CH}_{3}\right)$, $22.06\left(\mathrm{CH}_{2}\right), 22.51\left(\mathrm{CH}_{2}\right), 23.69\left(\mathrm{CH}_{2}\right), 27.66\left(\mathrm{CH}_{2}\right), 31.97\left(\mathrm{CH}_{2}\right)$, $33.96\left(\mathrm{CH}_{2}\right), 35.52\left(\mathrm{CH}_{2}\right), 35.81(\mathrm{CH}), 37.35\left(\mathrm{CH}_{2}\right), 38.83\left(\mathrm{CH}_{2}\right)$, $39.18(\mathrm{CH}), 40.83(\mathrm{C}), 43.71(\mathrm{CH}), 44.63(\mathrm{C}), 44.83\left(\mathrm{CH}_{2}\right), 55.74$ $(\mathrm{CH}), 56.11(\mathrm{CH}), 79.87(\mathrm{C}), 119.53(\mathrm{CH}), 165.89(\mathrm{C}), 181.43(\mathrm{C}=\mathrm{O})$, $197.03(\mathrm{C}=\mathrm{O}), 210.18(\mathrm{C}=\mathrm{O})$.

Spectroscopic data for $(25 S)-\Delta^{4,6,8(14)}$-dafachronic acid (23): Yellow crystals, mp $147-150{ }^{\circ} \mathrm{C} ;{ }^{13} \mathrm{C}$ NMR and DEPT $\left(125 \mathrm{MHz}, \mathrm{CDCl}_{3}\right): \delta=$ $16.62\left(\mathrm{CH}_{3}\right), 17.03\left(\mathrm{CH}_{3}\right), 18.74\left(\mathrm{CH}_{3}\right), 18.80\left(\mathrm{CH}_{3}\right), 18.95\left(\mathrm{CH}_{2}\right)$, $23.58\left(\mathrm{CH}_{2}\right), 25.30\left(\mathrm{CH}_{2}\right), 27.16\left(\mathrm{CH}_{2}\right), 33.98\left(\mathrm{CH}_{2}\right), 34.03\left(\mathrm{CH}_{2}\right)$, $34.07\left(\mathrm{CH}_{2}\right), 34.40(\mathrm{CH}), 35.43\left(\mathrm{CH}_{2}\right), 35.63\left(\mathrm{CH}_{2}\right), 36.73(\mathrm{C}), 39.36$ $(\mathrm{CH}), 44.12(\mathrm{CH}), 44.21(\mathrm{C}), 55.54(\mathrm{CH}), 122.90(\mathrm{CH}), 124.38(\mathrm{CH})$, $124.45(\mathrm{C}), 134.09(\mathrm{CH}), 156.09(\mathrm{C}), 164.60(\mathrm{C}), 182.42(\mathrm{C}=\mathrm{O})$, $199.77(\mathrm{C}=\mathrm{O})$.

$\S$ Crystal data for $(25 S)$-cholest-8(14)-en-3 $\beta, 26$-diol (15): $\mathrm{C}_{27} \mathrm{H}_{46} \mathrm{O}_{2}$, crystal size: $0.28 \times 0.25 \times 0.19 \mathrm{~mm}^{3}, M=402.64 \mathrm{~g} \mathrm{~mol}^{-1}$, monoclinic, space group: $P 2_{1}, \lambda=0.71073 \AA, a=11.0257(6), b=7.5583(4), c=$ 14.7907(9) $\AA, \beta=95.487(4)^{\circ}, V=1226.94(12) \AA^{3}, Z=2, \rho_{\mathrm{c}}=1.090 \mathrm{~g}$ $\mathrm{cm}^{-3}, \mu=0.066 \mathrm{~mm}^{-1}, T=198(2) \mathrm{K}, \theta$ range $=1.38-29.48^{\circ}$, reflections collected: 27556 , independent: $6718\left(R_{\text {int }}=0.0672\right), 274$ parameters. The structure was solved by direct methods and refined by full-matrix least-squares on $F^{2}$; final $R$ indices $[I>2 \sigma(I)]: R_{1}=0.0442, \mathrm{w} R^{2}=$ 0.0837; maximal residual electron density: 0.133 e $\AA^{-3}$. CCDC 867379.

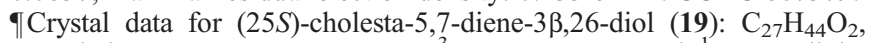
crystal size: $0.63 \times 0.15 \times 0.04 \mathrm{~mm}^{3}, M=400.62 \mathrm{~g} \mathrm{~mol}^{-1}$, monoclinic, space group: $P 2_{1}, \lambda=0.71073 \AA, a=11.658(3), b=6.105(2), c=$ $17.568(5) \AA, \beta=106.10(2)^{\circ}, V=1201.3(6) \AA^{3}, Z=2, \rho_{\mathrm{c}}=1.108 \mathrm{~g}$ $\mathrm{cm}^{-3}, \mu=0.067 \mathrm{~mm}^{-1}, T=150(2) \mathrm{K}, \theta$ range $=1.21-27.00^{\circ}$, reflections collected: 18278 , independent: $5131\left(R_{\text {int }}=0.1437\right), 274$ parameters. The structure was solved by direct methods and refined by full-matrix least-squares on $F^{2}$; final $R$ indices $[I>2 \sigma(I)]: R_{1}=0.0534, \mathrm{w} R^{2}=$ 0.0850; maximal residual electron density: $0.160 \mathrm{e} \AA^{-3}$. CCDC 867380.

1 (a) V. Matyash, E. V. Entchev, F. Mende, M. Wilsch-Bräuninger, C. Thiele, A. W. Schmidt, H.-J. Knölker, S. Ward and T. V. Kurzchalia, PLoS Biol., 2004, 2, 1561; (b) A. W. Schmidt, T. Doert, S. Goutal, M. Gruner, F. Mende, T. V. Kurzchalia and H.-J. Knölker, Eur. J. Org. Chem., 2006, 3687; (c) J. T. Hannich, E. V. Entchev, F. Mende, H. Boytchev, R. Martin, V. Zagoriy, G. Theumer, I. Riezman, H. Riezman, H.-J. Knölker and T. V. Kurzchalia, Dev. Cell, 2009, 16, 833; (d) D. Hochbaum, Y. Zhang, C. Stuckenholz, P. Labhart, V. Alexiadis, R. Martin, H.-J. Knölker and A. L. Fisher, PLoS Genet., 2011, 7, e1002179.

2 (a) D. L. Motola, C. L. Cummins, V. Rottiers, K. V. Sharma, T. Li, Y. Li, K. Suino-Powell, H. E. Xu, R. J. Auchus, A. Antebi and D. J. Mangelsdorf, Cell, 2006, 124, 1209; (b) V. Rottiers, D. L. Motola, B. Gerisch, C. L. Cummins, K. Nishiwaki, D. J. Mangelsdorf and A. Antebi, Dev. Cell, 2006, 10, 473; (c) B. Gerisch, V. Rottiers, D. Li, D. L. Motola, C. L. Cummins, H. Lehrach, D. J. Mangelsdorf and A. Antebi, Proc. Natl. Acad. Sci. U. S. A., 2007, 104, 5014.

3 (a) B. Gerisch, C. Weitzel, C. Kober-Eisermann, V. Rottiers and A. Antebi, Dev. Cell, 2001, 1, 841; (b) Z. Wang, X. E. Zhou, D. L. Motola, X. Gao, K. Suino-Powell, A. Conneely, C. Ogata, K. K. Sharma, R. J. Auchus, J. B. Lok, J. M. Hawdon, S. A. Kliewer, H. E. Xu and D. J. Mangelsdorf, Proc. Natl. Acad. Sci. U. S. A., 2009, 106, 9138.

4 V. A. Khripach, V. N. Zhabinskii, O. V. Konstantinova, N. B. Khripach, A. V. Antonchick, A. P. Antonchick and B. Schneider, Steroids, 2005, 70, 551.

5 (a) R. Martin, A. W. Schmidt, G. Theumer, T. V. Kurzchalia and H.J. Knölker, Synlett, 2008, 1965; (b) R. Martin, A. W. Schmidt, G. Theumer, T. Krause, E. V. Entchev, T. V. Kurzchalia and H.J. Knölker, Org. Biomol. Chem., 2009, 7, 909.

6 (a) R. Martin, F. Däbritz, E. V. Entchev, T. V. Kurzchalia and H.J. Knölker, Org. Biomol. Chem., 2008, 6, 4293; (b) R. Martin, E. 
V. Entchev, F. Däbritz, T. V. Kurzchalia and H.-J. Knölker, Eur. J. Org. Chem., 2009, 3703.

7 (a) S. Giroux and E. J. Corey, J. Am. Chem. Soc., 2007, 129, 9866; (b) S. Giroux and E. J. Corey, Org. Lett., 2008, 10, 801.

8 K. K. Sharma, Z. Wang, D. L. Motola, C. L. Cummins, D. J. Mangelsdorf and R. J. Auchus, Mol. Endocrinol., 2009, 23, 640.

9 A. Gioiello, P. Sabbatini, E. Rosatelli, A. Macchiarulo and R. Pelliciari, Tetrahedron, 2011, 67, 1924.

10 For a review, see: R. Martin, E. V. Entchev, T. V. Kurzchalia and H.J. Knölker, Org. Biomol. Chem., 2010, 8, 739.

11 T. Diao and S. S. Stahl, J. Am. Chem. Soc., 2011, 133, 14566.

12 W. Wang, J.-S. Lee, T. Nakazawa, K. Ukai, R. E. P. Mangindaan, D. S. Wewengkang, H. Rotinsulu, H. Kobayashi, S. Tsukamoto and M. Namikoshi, Steroids, 2009, 74, 758.
13 K. Chen, C. Liu, L. Deng and G. Xu, Steroids, 2010, 75, 513.

14 G. G. Mellado, E. Zubía, M. J. Ortega and P. J. López-González, J. Nat. Prod., 2005, 68, 1111.

15 H.-S. Kim, W. K. Wilson, D. H. Needleman, F. D. Pinkerton, D. K. Wilson, F. A. Quiocho and G. J. Schroepfer, J. Lipid Res., 1989, 30, 247.

16 D. Feldman, F. H. Glorieux and J. W. Pike, Vitamin D, Academic Press, San Diego, 1997.

17 (a) R. H. Shapiro, Org. React., 1976, 23, 405; (b) A. R. Chamberlain and S. H. Bloom, Org. React., 1990, 39, 1; (c) B. Hellrung, B. Voigt, J. Schmidt and G. Adam, Steroids, 1997, 62, 415.

18 J.-R. Rho, H.-S. Lee, Y. Seo, K. W. Cho and J. Shin, Bull. Korean Chem. Soc., 2000, 21, 518.

19 (a) D. H. R. Barton, T. Shioiri and D. A. Widdowson, J. Chem. Soc. C, 1971, 1968; (b) C. J. Moody, Adv. Heterocycl. Chem., 1982, 30, 1. 